See Article page 247.

\section{Commentary: How to kick the opioid habit in cardiac surgery?}

\author{
Subhasis Chatterjee, MD
}

Before the coronavirus disease 2019 (COVID-19) pandemic justifiably captured our focus, much of medicine was coming to a greater recognition of our collective responsibility in the opioid epidemic afflicting tens of thousands of people in the United States. In this month's issue of the Journal, Grant and colleagues ${ }^{1}$ provide an expert opinion piece addressing the role of opioid analgesia in cardiac surgery and the possibility of eliminating its use.

The first reaction by some will be to shout "Heresy!," whereas others may express casual indifference; after all, the overwhelming majority of patients receive opioidbased analgesia for surgery and do well without becoming addicted. So, why change?

Much has been observed regarding perioperative opioid exposure and subsequent opioid use. Persistent opioid use (POU) occurs when an opioid-naïve patient undergoes an operation, fills an opioid prescription within the perioperative time frame (from 30 days before surgery to 14 days after surgery), and continues to use opioids 90 to 180 days after the initial operation. ${ }^{2}$ POU has been identified in approximately $5 \%$ of patients after aortic dissection surgery, $6 \%-13 \%$ after coronary artery bypass grafting $(\mathrm{CABG})$ or valve surgery, and $14 \%-16 \%$ after thoracic surgery. ${ }^{3-5}$ Moreover, just as we know there is a strong direct relationship between the duration of cardiopulmonary

From the Divisions of General Surgery and Cardiothoracic Surgery, Michael E. DeBakey Department of Surgery, Baylor College Medicine; and Department of Cardiovascular Surgery, Texas Heart Institute, Houston, Tex.

Disclosures: The author holds a nonremunerated position of influence (Executive Board Member-Enhanced Recovery After Surgery Cardiac Society) and has served on the advisory boards of La Jolla Pharmaceuticals and Edwards Lifesciences.

The Journal policy requires editors and reviewers to disclose conflicts of interest and to decline handling or reviewing manuscripts for which they may have a conflict of interest. The editors and reviewers of this article have no conflicts of interest.

Received for publication April 23, 2021; revisions received April 23, 2021; accepted for publication April 26, 2021; available ahead of print May 18, 2021.

Address for reprints: Subhasis Chatterjee, MD, Baylor College of Medicine, One Baylor Plaza, MS: BCM 390, Houston, TX 77030-3411 (E-mail: subhasis. chatterjee@bcm.edu).

JTCVS Open 2021;7:255-6

2666-2736

Copyright (C) 2021 The Author(s). Published by Elsevier Inc. on behalf of The American Association for Thoracic Surgery. This is an open access article under the CC BY-NC-ND license (http://creativecommons.org/licenses/by-nc-nd/4.0/)

https://doi.org/10.1016/j.xjon.2021.04.015

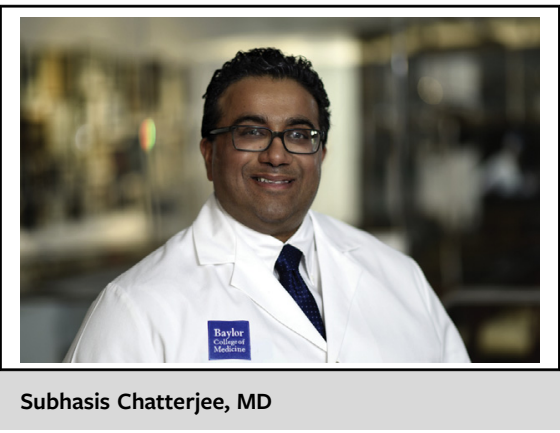

CENTRAL MESSAGE

Every opportunity to reduce opioid use in cardiac surgery should be welcomed, for the betterment of both the patient and the community at large.

bypass and the risk for developing acute kidney injury and other complications, so, too, is there a clear correlation between the opioid dosage during the immediate perioperative period, the amount prescribed at discharge, and the subsequent development of POU. ${ }^{5}$

As knowledge and awareness of the dangers of opioid use have grown, the tightrope that physicians must walk between overprescribing and underprescribing has become increasingly apparent. One large study of 25 different elective surgical procedures found that more than $60 \%$ of the opioid pills prescribed by physicians were not even used by the patient, whether through nonuse, misuse, or diversion. ${ }^{6}$ Conversely, despite concerns that physician reluctance to prescribe opioids will compromise patient satisfaction scores, ${ }^{7}$ recent evidence suggests that this is unlikely and that physicians should prescribe opioids appropriately, without fear of adverse impact on their satisfaction ratings. ${ }^{8}$

Grant and colleagues ${ }^{1}$ provide a useful guide to multiple nonopioid alternatives and techniques that can provide analgesia. The key is recognizing that there is no "one-size-fitsall" approach that will work. Clinicians need a Plan A, a Plan B, and a Plan C, because individual factors will determine treatment appropriateness and effectiveness in specific patients. Moreover, the authors offer a conceptual framework and Venn diagram ${ }^{1}$ that incorporate a multidisciplinary perspective (involving surgeons, anesthesiologists, intensivists, nurses, and pharmacists) on how to collaborate to move toward "kicking the opioid habit." This is where the Enhanced Recovery After Surgery cardiac 
framework, which promotes this kind of collaboration, can play an optimal role. Real-world examples at WakeMed Health and Hospitals ${ }^{9}$ and the Johns Hopkins Medical Institutions ${ }^{10}$ provide meaningful models that the global cardiac surgery community can build on and learn from to avoid the same pitfalls.

Another helpful step would be for the US Food and Drug Administration to review and ultimately revoke its 2005 "black box" warning on the use of ketorolac during CABG, given that multiple studies have shown that patients who undergo $\mathrm{CABG}$ can tolerate ketorolac without increased complications. ${ }^{11,12}$ Perhaps we might also look at opioids as we did packed red blood cell transfusions: Aim for zero usage, or as close to zero as possible. Indeed, packed red blood cell transfusion thresholds decreased from $10 \mathrm{~g} / \mathrm{dL}$ to $8 \mathrm{~g} / \mathrm{dL}$ and now to $7 \mathrm{~g} / \mathrm{dL}$, and yet overall surgical outcomes are better today than they have ever been.

This leads to one other observation. The field of cardiac surgery has consistently advanced because pioneers have thought in terms expressed by words variously attributed to George Bernard Shaw and then Robert F. Kennedy: "Some men see things as they are and say, why; I dream things that never were and say, why not." ${ }^{, 13}$ Examples of advances and practices that our surgical forefathers could not have imagined are too numerous to list, ranging from cardiac transplant and ventricular assist devices, to valve repair, minimally invasive surgery, and transcatheter and endovascular repairs, to extubation in the operating room. The fact that some of these advances-for example, transcatheter aortic valve replacement-are on a trajectory to become ambulatory procedure ${ }^{14}$ may provide the inspiration needed to continue pushing forward.

Ultimately, what will change behavior is for surgical societies, third-party payors, and the public to expect and demand a concerted effort from the collective health care system to find workable ways to reduce opioid use to zero.

\section{References}

1. Grant MC, Suffredini G, Cho BC. Is it time to eliminate the use of opioids in cardiac surgery? J Thorac Cardiovasc Surg Open. 2021;7:247-52.

2. Brummett CM, Waljee JF, Goesling J, Moser S, Lin P, Englesbe MJ, et al. New persistent opioid use after minor and major surgical procedures in US adults. JAMA Surg. 2017;152:e170504.

3. Clement KC, Canner JK, Sussman MS, Hicks CW, Sandhu HK, Estrera AL, et al. Persistent opioid use after open aortic surgery: risk factors, costs and consequences. Ann Thorac Surg. December 15, 2020 [Epub ahead of print].

4. Brescia AA, Waljee JF, Hu HM, Englesbe MJ, Brummett CM, Lagisetty PA, et al. Impact of prescribing on new persistent opioid use after cardiothoracic surgery. Ann Thorac Surg. 2019;108:1107-13.

5. Brown CR, Chen Z, Khurshan F, Groeneveld PW, Desai ND. Development of persistent opioid use after cardiac surgery. JAMA Cardiol. 2020;5:889-96.

6. Thiels CA, Ubl DS, Yost KJ, Dowdy SC, Mabry TM, Gazelka HM, et al. Results of a prospective, multicenter initiative aimed at developing opioid-prescribing guidelines after surgery. Ann Surg. 2018;268:457-68.

7. Sites BD, Harrison J, Herrick MD, Masaracchia MM, Beach ML, Davis MA. Prescription opioid use and satisfaction with care among adults with musculoskeletal conditions. Ann Fam Med. 2018;16:6-13.

8. Secrist E, Wally MK, McKnight R, Van Demark R, Seymour RB, Karunakar M, et al. Opioid prescribing and patient satisfaction scores across practice types. $J$ Surg Orthop Adv. 2020;29:5-9.

9. Williams JB, McConnell G, Allender JE, Woltz P, Kane K, Smith PK, et al. Oneyear results from the first US-based enhanced recovery after cardiac surgery (ERAS Cardiac) program. J Thorac Cardiovasc Surg. 2019;157:1881-8.

10. Grant MC, Isada T, Ruzankin P, Whitman G, Lawton JS, Dodd-O J, et al. Results from an enhanced recovery program for cardiac surgery. J Thorac Cardiovasc Surg. 2020;159:1393-402.e7.

11. Oliveri L, Jerzewski K, Kulik A. Black box warning: is ketorolac safe for use after cardiac surgery? J Cardiothorac Vasc Anesth. 2014;28:274-9.

12. Howard ML, Warhurst RD, Sheehan C. Safety of continuous infusion ketorolac in postoperative coronary artery bypass graft surgery patients. Pharmacy (Basel). 2016;4:22.

13. Text of Edward Kennedy's tribute to his brother in cathedral. The New York Times. June 9, 1968

14. Zouaghi O, Wintzer-Wehekind J, Lienhart Y, Abdellaoui M, Faurie B. Ambulatory TAVR: early feasibility experience during the COVID-19 pandemic. CJC Open. 2020;2:729-31. 